\title{
Kontribusi hiperglikemia dan hipoalbuminemia terhadap multiple organ dysfunction syndrome (MODS) pada pasien multitrauma
}

\author{
${ }^{1}$ Hendri, ${ }^{2}$ Heber B. Sapan, ${ }^{2}$ Harsali F. Lampus \\ ${ }^{1}$ Program Studi Ilmu Bedah Fakultas Kedokteran Universitas Sam Ratulangi Manado \\ ${ }^{2}$ KSM Ilmu Bedah RSUP Prof. Dr. R. D. Kandou Manado \\ ${ }^{3}$ Bagian Ilmu Bedah Fakultas Kedokteran Universitas Sam Ratulangi Manado \\ Email: gintingdr@yahoo,com
}

\begin{abstract}
Recent randomized prospective data suggest that early hyperglycemia and hypoalbuminemia are associated with MODS in multitrauma patients. This study was aimed to determine the contribution of early blood glucose elevation and decreased serum albumin in Trauma Emergency Department or ICU patients. We prospectively collected multitrauma patients with Injury Severity Score (ISS) $\geq 18$, blood glucose, serum albumin, aged 14-81 years old, admitted to level I Trauma Centre at Prof. Dr. R. D. Kandou General Hospital Manado from September 2015 through July 2016. Sequential Organ Failure Assessment (SOFA) score was used to determine MODS during hospitalization. The $\mathrm{X}^{2}$ (Fisher exact) test was used to determine the level of significance and odd ratio was used to determine the risk estimation. There were 51 multitrauma patients in this study. The mean age was 31.73 years old; 41 males $(80.4 \%)$ and 10 females $(19.6 \%)$; blood glucose level $>126 \mathrm{mg} / \mathrm{dl}$ occurred in 34 patients $(66.7 \%)$ and $\leq 126 \mathrm{mg} / \mathrm{dL}$ occurred in 17 patients $(33.3 \%)$. Serum albumin level $<3.5 \mathrm{gr} / \mathrm{dL}$ occurred in 31 patients $(60.8 \%)$ and $\geq 3,5$ gr/dl occurred in 20 patients $(39.2 \%)$. Conclusion: Early hyperglycemia (blood glucose level $>126 \mathrm{mg} / \mathrm{dL}$ ) and hypoalbuminemia (serum albumin $<3.5 \mathrm{gr} / \mathrm{dL}$ ) were associated with significantly higher MODS rates in multitrauma patients independently of injury characteristics. The present of early hyperglycemia and hypoalbuminemia may allow early identification of trauma patients who are at risk for MODS.

Keywords: multitrauma, hyperglycemia, hypoalbuminemia, MODS
\end{abstract}

\begin{abstract}
Abstrak: Data prospektif secara random menunjukkan bahwa adanya hiperglikemia dan hipoalbuminemia dapat berisiko terhadap terjadinya MODS pada pasien dengan multitrauma. Penelitian ini bertujuan untuk menentukan kontribusi hiperglikemia dan hipoalbuminemia pada pasien yang dirawat di Instalasi Gawat Darurat maupun di ICU. Data diambil secara prospektif pada pasien multitrauma dengan Injury Severity Score (ISS) $\geq 18$, kadar gula darah dan serum albumin, usia 14-81 tahun yang datang ke Pusat Trauma RSUP Prof Dr. R. D. Kandou Manado selama 11 bulan (September 2015 s/d Juli 2016). Digunakan Sequential Organ Failure Assessment (SOFA) skor untuk menentukan MODS selama dirawat. Data dianalisis dengan $\mathrm{X}^{2}$ atau Fisher exact test untuk tingkat signifikansi dan odd ratio untuk menentukan perkiraan tingkat kesalahan. Hasil penelitian mendapatkan total 51 pasien yang termasuk dalam kriteria inklusi. Rerata usia 31,73 tahun, laki-laki 41 pasien $(80,4 \%)$ dan perempuan 10 pasien $(19,6 \%)$. Kadar gula darah $>126 \mathrm{mg} / \mathrm{dl}$ sebanyak 34 pasien $(66,7 \%)$ dan kadar gula darah $\leq 126 \mathrm{mg} / \mathrm{dl}$ sebanyak 17 pasien $(33,3 \%)$. Kadar albumin $<3,5 \mathrm{gr} / \mathrm{dl}$ sebanyak 31 pasien $(60,8 \%)$ dan kadar albumin $\geq 3,5$ gr/dl sebanyak 20 pasien $(39,2 \%)$. Simpulan: Hiperglikemia dengan kadar gula darah $>126 \mathrm{mg} / \mathrm{dl}$ dan hipoalbuminemia dengan kadar albumin $<3,5 \mathrm{gr} / \mathrm{dl}$ sangat berisiko untuk terjadi MODS pada pasien-pasien trauma namun tergantung dari beratnya cedera yang dialami. Adanya hiperglikemia dan hipoalbuminemia merupakan tanda awal terhadap risiko terjadinya MODS pada pasien multitrauma.
\end{abstract}

Kata kunci: multitrauma, hiperglikemia, hipoalbuminemia, MODS 
Hiperglikemia dan hipoalbuminemia paling sering terjadi pada pasien sakit berat yang berakibat meningkatnya angka morbiditas dan mortalitas. Respon stres setelah cedera merangsang resistensi insulin dan secara keseluruhan terjadi hiperglikemia yang merupakan efek sekunder dari pelepasan kortikosteroid, growth hormone, glukagon, dan katekolamin. Kadar hiperglikemia setelah trauma berhubungan dengan beratnya cedera yang dialami pasien. ${ }^{1-3}$

Trauma juga dapat merangsang pelepasan sitokin yang akan meningkatkan permeabilitas kapiler, dilusi serum albumin melalui pemberian infus, serta berpindahnya albumin dari peredaran darah. ${ }^{4,5}$ Terjadinya hiperglikemia dan hipoalbuminemia pada pasien trauma sudah lama dilaporkan; keduanya merupakan prediktor terhadap meningkatnya morbiditas dan mortalitas. $^{4-7}$

\section{METODE PENELITIAN}

Data diambil secara prospektif pada pasien multitrauma dengan Injury Severity Score (ISS) $\geq 18$ yaitu kadar gula darah dan serum albumin dari pasien berusia 14-81 tahun yang datang ke Pusat Trauma RSUP Prof Dr. R. D. Kandou Manado selama 11 bulan mulai September 2015 hingga Juli 2016. Kadar gula darah dan albumin serum diperiksa pada masing-masing pasien. Berdasarkan kadar gula darah pasien dibagi atas kadar gula darah $\leq 126 \mathrm{mg} / \mathrm{dL}$ vs $>126$ $\mathrm{mg} / \mathrm{dL}$, dan berdasarkan kadar albumin serum $\geq 3,5 \mathrm{gr} / \mathrm{dL}$ vs $<3,5 \mathrm{gr} / \mathrm{dL}$. Pasien yang sebelum cedera menyandang diabetes melitus (DM) dieksklusi dari penelitian agar terjadinya stres akut hiperglikemia dan DM tidak tumpang tindih karena pada penelitian ini tidak dilakukan pemeriksaan HbA1c sehingga terdapat kemungkinan pasien DM masuk dalam kriteria inklusi. Riwayat penyakit dianamnesis kepada pasien maupun keluarganya bila pasien tidak bisa dianamnesis secara langsung. Pasien yang menderita penyakit kronik atau riwayat trauma berat dieksklusi dalam penelitian ini.

Sequential Organ Failure Assessment (SOFA) skor digunakan untuk menentu- kan MODS selama dirawat di rumah sakit. Skor SOFA menilai disfungsi organ dan kegagalan organ terhadap enam organ. SOFA ditentukan dari $\mathrm{PaO} 2 / \mathrm{FiO} 2$ rasio (sistem respirasi), jumlah platelet (sistem hematologi), GCS (sistem saraf pusat), mean arterial pressure dan inotropik (sistem kardiovaskular), urine output dan kadar kreatinin (sistem renal) dan total bilirubin (sistem hepatobiliar-saluran cerna). Dikatakan MODS bila skor SOFA 1 atau 2 poin dan MOF jika skor SOFA $\geq 3$ yang mengenai paling sedikit 2 organ atau lebih. ${ }^{8} \mathrm{Uji}^{2}$ (Fisher exact test) untuk menentukan tingkat signifikansi dan odd ratio untuk menentukan perkiraan tingkat kesalahan.

\section{HASIL PENELITIAN}

Secara keseluruhan terdapat 51 pasien multitrauma yang masuk kriteria inklusi pada penelitian ini terdiri dari 41 orang laki-laki $(80,4 \%)$ dan 10 orang perempuan $(19,6 \%)$ dengan rerata usia 31,73 tahun Mayoritas 48 pasien (94\%) dirawat karena kecelakaan lalu lintas; sisanya 2 pasien (4\%) jatuh dari ketinggian; dan 1 pasien (2\%) disebabkan luka tusuk.

Dari semua pasien dengan kadar gula darah $>126 \mathrm{mg} / \mathrm{dl}$ terdapat sebanyak 34 orang $(66,7 \%)$ dan kadar gula darah $\leq 126$ mg/dl sebanyak 17 orang $(33,3 \%)$. Kadar albumin serum <3,5 gr/dL sebanyak 31 orang $(60,8 \%)$ dan kadar albumin serum $\geq 3,5 \mathrm{gr} / \mathrm{dL}$ sebanyak 20 orang $(39,2 \%)$. Pasien dengan kadar gula darah $>126$ $\mathrm{mg} / \mathrm{dL}$ yang mengalami MODS sebanyak 30 orang $(78,9 \%)$ dan kadar gula darah $\leq$ $126 \mathrm{mg} / \mathrm{dl}$ yang mengalami MODS sebanyak 8 orang $(21,1 \%)$; sisanya tidak mengalami MODS. Pasien dengan kadar serum albumin $<3,5 \mathrm{gr} / \mathrm{dL}$ yang mengalami MODS sebanyak 30 orang $(78,9 \%)$ dan kadar serum albumin $\geq 3,5 \mathrm{gr} / \mathrm{dL}$ sebanyak 8 orang $(21,1 \%)$ (Tabel 2$)$.

Pasien dengan kadar gula darah $>126$ $\mathrm{mg} / \mathrm{dL}$ memiliki resiko mengalami MODS lebih tinggi dibanding pasien yang kadar glukosa $\leq 126 \mathrm{mg} / \mathrm{dL}$. Pasien MODS kebanyakan mengalami kadar gula darah tinggi 24 jam pertama perawatan $(P<$ 
0,001) yang bermakna secara statistik dengan perkiraan kesalahan odds ratio $[\mathrm{OR}]=8,438(95 \%$ confidence interval $[\mathrm{CI}]$ : 2,05-34,6).

Pasien dengan kadar albumin serum $<3,5 \mathrm{gr} / \mathrm{dL}$ memiliki resiko mengalami MODS lebih tinggi daripada pasien dengan kadar albumin serum $\geq 3,5 \mathrm{gr} / \mathrm{dl}$. MODS cenderung terjadi pada pasien dengan kadar albumin rendah dalam 72 jam setelah perawatan $(P<0,001)$ yang secara statistik bermakna dengan perkiraan kesalahan odds ratio $[\mathrm{OR}]=45,000 \quad(95 \%$ confidence interval $[\mathrm{CI}]: 5.06-399,68)$.

Tabel 2. Tabulasi silang kadar gula darah * MODS

\begin{tabular}{ccccc}
\hline $\begin{array}{c}\text { Kadar gula } \\
\text { darah }\end{array}$ & Positif & MODS & Total & \multirow{2}{*}{$\mathbf{X}^{2}$ test } \\
\hline$>126 \mathrm{mg} / \mathrm{dl}$ & 30 & 4 & 34 & \\
& $78,9 \%$ & $30,8 \%$ & $66,7 \%$ & \\
$\leq 126 \mathrm{~g} / \mathrm{dl}$ & 8 & 9 & 17 & $\mathrm{X}^{2}=10,117$ \\
& $21,1 \%$ & $69,2 \%$ & $33,3 \%$ & $(P<0,001)$ \\
Total & 38 & 13 & 51 & \\
\hline OR $=8,438(95 \% \mathrm{CI}: 2,05-34,6)$ & $100,0 \%$ & $100,0 \%$ & \\
\end{tabular}

Tabel 3. Tabulasi silang kadar albumin serum* MODS

\begin{tabular}{ccccc}
\hline $\begin{array}{c}\text { Kadar albumin } \\
\text { serum }\end{array}$ & Positif & Negatif & Total & \multirow{2}{*}{$\mathbf{X}^{2}$ test } \\
\hline$<3,5 \mathrm{gr} / \mathrm{dl}$ & 30 & 1 & 31 & \\
& $78,9 \%$ & $7,7 \%$ & $60,8 \%$ & \\
$\geq 3,5 \mathrm{gr} / \mathrm{dl}$ & 8 & 12 & 20 & $\mathrm{X}^{2}=20,632$ \\
& $21,1 \%$ & $92,3 \%$ & $39,2 \%$ & $(P<0,001)$ \\
Total & 38 & 13 & 51 & \\
& $100,0 \%$ & $100,0 \%$ & $100,0 \%$ & \\
\hline
\end{tabular}

$\mathrm{OR}=45,000(95 \%$ CI: 5,06-399,68)

\section{BAHASAN}

Adanya hiperglikemia dan hipoalbuminemia merupakan tanda pada pasien trauma yang berisiko untuk terjadi MODS. ${ }^{9,10}$ Hiperglikemia dengan kadar gula darah >126 $\mathrm{mg} / \mathrm{dl}$ dan hipoalbuminemia dengan kadar albumin serum <3,5 gr/dL memiliki angka MODS yang tinggi pada pasien multitrauma tergantung dari pola cedera.

Telah lama diketahui bahwa adanya hiperglikemia setelah trauma merupakan suatu tanda gangguan fisiologi dengan risiko mortalitas yang tinggi disebabkan oleh MODS. Penelitian sebelumnya menyatakan bahwa adanya hiperglikemia meningkatkan mortalitas pada pasien trauma. Sung et al. ${ }^{11}$ menyatakan dalam analisis prospectif terhadap 1.003 pasien trauma memiliki tiga kali lipat lebih tinggi terjadi komplikasi infeksi. Demikian pula dengan hasil penelitian Yendamuri et al. ${ }^{12}$ yang menyatakan hiperglikemia memiliki risiko tiga kali lipat mengalami pneumonia dan infeksi saluran kencing.

Albumin merupakan protein plasma yang mempunyai efek terhadap stabilisasi sel endotel dan mengatur permeabilitas kapiler. Serum albumin dapat berubah pada kondisi dehidrasi, sepsis, trauma, gangguan hati, serta gangguan nutrisi. Stres yang disebabkan oleh trauma maupun pembedahan meningkatkan pemakaian energi dan protein dengan membuat status hipermetabolik dan katabolik. Keadaan seperti ini dapat menimbulkan malnutrisi protein dan kalori dalam beberapa hari. ${ }^{4,5}$

Adanya hipoalbuminemia memiliki 
resiko komplikasi infeksi dan penyembuhan yang kurang baik selama di Rumah Sakit dibanding pasien yang memiliki albumin yang normal. Penelitian Yuki et al. ${ }^{13}$ yang menggunakan retrospective matched-pair study terhadap pasien trauma tumpul (terdiri dari 51 pasien yang meninggal dan 51 pasien yang berhasil selamat) di Unit Gawat Darurat menyimpulkan bahwa pasein yang mengalami hipoalbuminemia dengan kadar albumin $<3,4 \mathrm{gr} / \mathrm{dl}$ memiliki risiko $2,5 \mathrm{kali}$ lipat meninggal dibanding pasien dengan kadar albumin yang normal.

\section{SIMPULAN}

Hiperglikemia dan hipoalbuminemia memiliki resiko yang tinggi terhadap terjadinya MODS pada pasien multitrauma. Adanya hiperglikemia dan hipoalbuminemia merupakan tanda bahwa beresiko terhadap terjadinya MODS dan memerlukan penanganan dan resusitasi yang agresif. Penelitian lebih lanjut perlu dilakukan apakah perlu pemberian antiinflamasi untuk mencegah hipoalbuminemia.

\section{DAFTAR PUSTAKA}

1. Laird AM, Miller PR, Kilgo PD, Meredith JW, Chang MC. Relationship of early hyperglycemia to mortality in trauma patients. J Trauma. 2004;56:1058-62.

2. Sperry JL, Frankel HL, Vanek SL, Nathens AB, Moore EE, Maier RV, et al. Early hyperglycemia predicts multiple organ failure and mortality but not infection. J Trauma. 2007;63:487-94.

3. Cochran A, Scaife ER, Hansen KW, Downey EC. Hyperglycemia and outcomes from pediatric traumatic brain injury. J Trauma. 2003;55:1035-8.

4. Boldt J. Use of albumin: an update. BJA. 2010;104(3):276-84.
5. Jin GX, Li L, Cui SQ, Duan JZ, Wang H. Persistent hypoalbuminemia is a predictor of outcome in cervical spinal cord injury. Spine J. 2014;14;1902-8.

6. Tiwari LK, Singhi S, Jayashree M, Baranwal AK, Bansal A. Hypoalbuminemia in critically sick children. Indian $\mathrm{J}$ Crit Care Med 2014;18:565-9.

7. Brackney CR, Diaz LA, Milbrandt EB, AlKhafaji A, Darby JM. Is albumin use safe in patients with traumatic brain injury? Crit Care. 2010; 14:307.

8. 8Jones AE, Trzeciak S, Kline AJ. The sequential organ failure assessment score for predicting outcome in patients with severe sepsis and evidence of hypoperfusion at the time of emergency department presentation. Crit Care Med. 2009;37(5):1649-54.

9. Wahl WL, Taddonio M, Maggio PM, Arbabi S, Mark R. Hemmila MR. Mean glucose values predict trauma patient mortality. J Trauma. 2008;65:428.

10. Kreutziger J, Schlaepfer J, Volker Wenzel V, Constantinescu MA. The role of admission blood glucose in outcome prediction of surviving patients with multiple injuries. J Trauma. 2009;67: 704-8.

11. Sung J, Bochicchio GV, Joshi M, Bochicchio K, Tracy K, Scalea TM. Admission hyperglycemia is predictive of outcome in critically ill trauma patients. $\mathbf{J}$ Trauma. 2005;59:80-3.

12. Yendamuri S, Fulda GJ, Tinkoff GH. Admission hyperglycemia as a prognostic inducator in trauma. $\mathbf{J}$ Trauma. 2003;55(1):33-8.

13. Yuki RL, Bar-Or D, Harris L, Shapiro $H$, Winkler JV. Low albumin level in the emergency deparment: a potential independent predictor of delayed mortality in blunt trauma. J Emerg Med. 2003;25(1):1-6. 